\title{
Root Growth, Mycorrhizal Frequency and Soil Microorganisms in Strawberry as Affected by Biopreparations
}

\author{
Edyta Derkowska*, Lidia Sas Paszt, Anton Harbuzov, Beata Sumorok \\ Research Institute of Horticulture, Skierniewice, Poland \\ Email: ${ }^{*}$ edyta.derkowska@inhort.pl
}

Received 2 January 2015; accepted 22 January 2015; published 29 January 2015

Copyright (C) 2015 by authors and Scientific Research Publishing Inc.

This work is licensed under the Creative Commons Attribution International License (CC BY). http://creativecommons.org/licenses/by/4.0/

(c) () Open Access

\begin{abstract}
The aim of the study was to assess the effects of various biopreparations on the growth of the strawberry root system, the number of spores of mycorrhizal fungi, the total number of bacteria in the rhizosphere soil, and the degree of mycorrhizal association in the roots of two strawberry cultivars. The experiment with strawberry plants was established in the spring of 2010 in the Experimental Orchard of the Institute of Horticulture in Dąbrowice. The objects of research were "frigo" strawberry plants of the cultivars Elsanta and Elkat. The following experimental combinations were used: control, control NPK (standard NPK fertilization), manure, mycorrhizal preparation Micosat F, Humus UP, Humus Active + Aktywit PM, BioFeed Amin, BioFeed Quality, Tytanit, Vinassa, Florovit Eko, and Florovit Pro Natura. The use of the biopreparation BioFeed Quality resulted in a six-fold increase in root length and a seven-fold increase in root surface area. Compared with NPK fertilization, application of the preparation BioFeed Amin contributed to an eight-fold increase in root volume, and the use of Vinassa increased 24-fold the number of root tips of Elkat strawberry plants. Micosat $F$ and Humus UP caused a five-fold increase in mycorrhizal frequency in the roots of strawberry plants. Micosat $F$ and manure contributed to a two- and four-fold increase, respectively, in the number of spores in the rhizosphere soil. Application of the preparations Humus UP, BioFeed Amin and Florovit Eko doubled the total number of bacteria and filamentous fungi in the rhizosphere soil of strawberry plants of the cultivars Elsanta and Elkat in comparison with NPK fertilization. Fertilization with the biopreparations intensified the growth of the root system and increased the number of spores of AM fungi, mycorrhizal frequency, and the total number of bacteria and filamentous fungi in the soil.
\end{abstract}

\section{Keywords}

AM Fungi, Root System, Colonization, Bioproducts, Bacteria, Fragaria $x$ ananassa

\footnotetext{
${ }^{*}$ Corresponding author.
}

How to cite this paper: Derkowska, E., Paszt, L.S., Harbuzov, A. and Sumorok, B. (2015) Root Growth, Mycorrhizal Frequency and Soil Microorganisms in Strawberry as Affected by Biopreparations. Advances in Microbiology, 5, 65-73. 


\section{Introduction}

To obtain high yields in intensive horticultural and agricultural production, high levels of mineral fertilization combined with the application of chemical plant protection products are commonly used. This results in a loss of the biological potential and erosion of soils, which leads to deterioration in the quality and fertility of cultivated soils. An alternative to such production is the use of manure, introduction into the soil of straw and natural bioproducts, i.e. biofertilizers, biostimulators, composts and microbially-enriched biopesticides. This applies in particular to fields used for agricultural purposes, to fields that are being prepared for new plantings, and in regions with a high intensity of fruit crops, where there is no possibility of applying the commonly prescribed rotation of crops. The activity of symbiotic microorganisms in the rhizosphere is a factor determining the growth of the plant and its resistance to pathogens [1]-[3]. Arbuscular mycorrhizal fungi is an important component of the rhizosphere; the presence of the mycelium helps to increase the absorptive surface of roots and the availability of phosphorus, nitrogen, potassium, iron, manganese and other micronutrients to plants [4]. Rhizosphere bacteria support the development of mycorrhizal fungi, and stimulate the growth and yielding of many plant species [5].

Research by numerous authors suggests that it is precisely the microorganisms living in a natural symbiosis with plants that releases the components necessary for normal growth and development of plants. In this context, what is important in all communities are the right proportions, development and activity of rhizosphere components, including not only the soil surrounding the roots, but also symbiotic organisms, i.e. rhizosphere bacteria, mycorrhizal fungi, saprotrophic fungi, predatory protozoa and nematodes. The activity of beneficial microflora in the rhizosphere is not only one of the factors determining normal plant growth, but also an important potential source of their resistance to infectious diseases [6]-[8]. With the presence of rhizosphere bacteria and mycorrhizal fungi, the absorptive surface of plant roots increases and thus the effectiveness of the uptake by plants of minerals, mainly phosphorus, potassium, magnesium, and other macro- and micro-elements. Arbuscular mycorrhizal fungi and rhizosphere bacteria are also used on degraded soils as natural biofilters, neutralizing and accumulating chemical contaminants of soils. One of the main factors that ensure optimal conversion of organic matter in soils is a suitable population size and activities of beneficial microorganisms. Preparations containing humic compounds increase the humus content in the soil and biological activity of the rhizosphere, stimulate the growth and development of crops, and have a protective effect against soil pathogens and diseases of crop plants [9]-[12]. As a result, plants develop and grow better, which translates into better yields and quality of the crops produced. Nutrient depletion and progressive degradation of agricultural and horticultural soils, and replantation diseases create the need for developing microbiological plant cultivation and fertilization techniques based on natural organic bioproducts and beneficial microorganisms (bacteria, mycorrhizal fungi, and filamentous fungi) to increase the biodiversity of microorganisms in the rhizosphere and their antagonistic effects on harmful microorganisms [13] [14]. These microorganisms can also produce biologically active compounds (vitamins, growth regulators, antibiotics, siderophores, and nutrients for plants), improving the quality of cultivated soils and the growth and yielding of crop plants [15]-[17].

The aim of this study was to determine the effects of various bioproducts on root growth characteristics, the number of spores of rbuscular mycorrhizal fungi, and the total number of bacteria in the rhizosphere soil, as well as the degree of arbuscular mycorrhizal association in the roots of two strawberry cultivars Elsanta and Elkat.

\section{Materials and Methods}

The experiment was conducted in the Experimental Orchard of the Institute of Horticulture in Dąbrowice. "Frigo" strawberry plantlets of the cultivars Elsanta and Elkat were planted in the spring of 2010 in 4 replications (each consisting of 20 strawberry plants per plot). The plants were grown at a spacing of $1.0 \mathrm{~m} \times 0.25 \mathrm{~m}$ with a 0.5 -metre-wide isolation strip between the plots. The following combinations were used in a randomized block design:

1) Control (no NPK fertilization, no application of bioproducts);

2) Control NPK (70 kg N ha $\left.{ }^{-1}, 60 \mathrm{~kg} \mathrm{Pha}^{-1}, 120 \mathrm{~kg} \mathrm{~K}_{2} \mathrm{O} \mathrm{ha}^{-1}\right)$;

3) Manure- "Fertigo" granulated bovine manure (Ferm-O-Feed, Holland);

4) Micosat F (Micosat F12 and Micosat F MS 200, preparations of the Italian company CCS Aosta, a mixture of AM fungi: Glomus species, Trichoderma viride, and rhizosphere bacterial species (Bacillus subtilis, Pseudomonas fluorescens and Streptomyces spp.); 
5) Humus UP (product of Ekodarpol; an extract derived from organic manure produced with the help of Californian earthworms);

6) Humus Active + Aktywit PM (products of Ekodarpol; Humus Active-an extract from organic manure produced with the help of Californian earthworms; Aktywit PM-an activator of microbial life, produced on the basis of molasses (containing carbohydrates, mineral nutrients, vitamins and amino acids);

7) BioFeed Amin (product of Koppert; an extract containing plant amino acids);

8) BioFeed Quality (product of Koppert; a seaweed extract containing humic and fulvic acids);

9) Tytanit (product of Intermag Company, mineral stimulator of growth, containing element titanium, amino acids, vitamins, algae extract, humic and fulvic acids, macro and microelements);

10) Vinassa (produced by Mazowiecka Fabryka Drożdży Józefów; a waste from the production of baker's yeast);

11) Florovit Eko (product of Inco-Veritas; contains lignite, potassium sulphate, phosphate, dolomite, bentonite, and molasses);

12) Florovit Pro Natura (product of Inco-Veritas; contains lignite, urea, potassium sulphate, ammonium phosphate, dolomite, and molasses).

The experiment included control plants that were not fertilized with NPK, nor treated with any bioproducts. There were also control plants that were fertilized with NPK each year in the spring, in doses of $70 \mathrm{~kg} \mathrm{~N} \mathrm{ha}^{-1}$ as $\mathrm{NH}_{4} \mathrm{NO}_{3}, 60 \mathrm{~kg} \mathrm{Pha}^{-1}$ as $\mathrm{P}_{2} \mathrm{O}_{5}$, and $120 \mathrm{~kg} \mathrm{~K}_{2} \mathrm{O}$ ha $^{-1}$ as $\mathrm{K}_{2} \mathrm{SO}_{4}$ ). Manure was applied at a rate of $1500 \mathrm{~kg} \cdot \mathrm{ha}^{-1}$. Mycorrhizal preparations were applied two times: first, Micosat F12 was applied to the root system when plants were being planted-100 $\mathrm{kg} \cdot \mathrm{ha}^{-1}$, and then, 2 weeks after the first application, Micosat F MS 200 was applied to the leaves at $10 \mathrm{~kg} \cdot \mathrm{ha}^{-1}$. The preparation Humus UP was applied to the soil as a $2 \%$ solution at $20 \mathrm{l} \cdot \mathrm{ha}^{-1}$. Humus Active was applied to the soil as a $2 \%$ solution at $201 \cdot \mathrm{ha}^{-1}$ in conjunction with a $1 \%$ solution of Aktywit PM applied to the soil at $101 \cdot \mathrm{ha}^{-1}$. The preparation BioFeed Amin was applied to the soil as a $0.5 \%$ solution at $5 \mathrm{l} \cdot \mathrm{ha}^{-1}$. BioFeed Quality was applied to the soil as a $0.5 \%$ solution at $51 \cdot \mathrm{ha}^{-1}$. The stimulator Tytanit was applied to eaves as a $0.05 \%$ solution at $0.51 \cdot \mathrm{ha}^{-1}$. Vinassa was applied to the soil as a $0.5 \%$ solution at $5 \mathrm{l} \cdot \mathrm{ha}^{-1}$. The fertilizers Florovit Eko and Florovit Pro Natura were applied to the soil at a rate of $1500 \mathrm{~kg} \cdot \mathrm{ha}^{-1}$.

In addition to the applications of the biopreparations Micosat F, BioFeed Amin, BioFeed Quality, Tytanit and Vinassa, fertilization with manure was applied at $750 \mathrm{~kg} \cdot \mathrm{ha}^{-1}(1 / 2$ dose). The experiment lasted until 2013.

\subsection{Microbiological Analysis}

Soil samples (5 g each), collected in July 2013, were placed in distilled water (45 $\mathrm{ml}$ ) so that $1 \mathrm{ml}$ of the suspension would contain $0.1 \mathrm{~g}$ of soil, and then shaken for 40 minutes on a shaker $\left(150 \mathrm{rev} \cdot \mathrm{min}^{-1}\right)$. The suspension thus prepared was used to make a series of successive ten-fold dilutions $\left(10^{-2}, 10^{-3}, 10^{-4}, 10^{-5}\right.$ and $\left.10^{-6}\right)$. The dilutions were placed in Petri dishes containing suitable culture media.

The total number of bacteria was estimated by spreading $100 \mu$ portions of the suspension in Petri dishes containing the medium Tryptone Soy Agar 20\% (TSA) [18]. To estimate the total number of fungi, $100 \mu$ l portions of the suspension were placed onto plates containing the medium Rose Bengal Chloramphenicol Agar [19].

The inoculated Petri plates with $20 \%$ TSA were incubated for 7 days at $28^{\circ} \mathrm{C}$ and the inoculated plates with Rose Bengal Chloramphenicol Agar were incubated at $25^{\circ} \mathrm{C}$ for $5-7$ days. The microorganisms' population was estimated by counting the bacterial and fungal colonies that grew in the inoculated petri plates. When calculating the number of bacteria and fungi, only the plates on which the number of colonies was $30-300$ were taken into account. The results were converted to colony-forming units per 1 gram dry weight of soil $\left(\mathrm{cfu}^{-1} \mathrm{~g}^{-1} \mathrm{DW}_{\mathrm{s}}\right)(\mathrm{Table}$ 4). The content of the dry mass in the growing medium was estimated by heating it in electric oven, at $105^{\circ} \mathrm{C}$ for 24 hours.

\subsection{Assessment of the Degree of Colonization of Roots by Arbuscular Mycorrhizal Fungi}

Roots collected in July 2013 (10 g from each replication) were stained according to the method developed at the Rhizosphere Laboratory of the Agrotechnical Department of the Institute of Horticulture [20]. Preparation of root fragments for testing proceeded in the following steps:

1) Maceration of root tissues with $10 \%$ sodium hydroxide $(\mathrm{NaOH})$ at $65^{\circ} \mathrm{C}$ for $30 \mathrm{~min}$.;

2) Washing out roots from the $\mathrm{NaOH}$ solution with water -5 min.;

3) Acidification of roots with $10 \%$ lactic acid-10 min., 
4) Staining roots with carbol fuchsin for $10 \mathrm{~min}$;

5) Rinsing roots with water to remove excess dye-10 min.;

6) Preservation and storage of roots in glycerol.

Next, microscopic specimens were prepared by selecting from each replicate 30 the thinnest and the lightest in colour root fragments approx. $1 \mathrm{~cm}$ long ( 3 microscopic specimens were prepared per each replicate), laying them out parallel to one another on a microscope slide containing glycerin, and crushing them with a coverglass. Thus prepared histological specimens were analyzed using a Nikon 50i microscope (with $20 \times$, 40×, 60× and $100 \times$ objectives), and photographic records were made of the mycorrhizal structures observed. The degree of root colonization by AGM as assessed using the method of Trouvelot [21]. The results were used to calculate mycorrhizal frequency ( $\mathrm{F} \%$ ) with a computer program MYCOCALC available on the website:

http://www2.dijon.inra.fr/mychintec/Mycocalc-prg/download.html (Table 3).

\subsection{Determination of Root Growth Characteristics}

Root fragments together with soil were collected at a distance of $15-20 \mathrm{~cm}$ from the strawberry plants in July 2013 , using a cork borer with a volume of 0.51 . The root system obtained in this way was placed on a sieve and gently rinsed with water to wash away the soil. After drying, the roots were scanned using an EPSON EXPRESSION 10000 XL root scanner. Root growth characteristics were determined using the WinRhizo software [22]. The following growth parameters were determined: root length, root surface area, root diameter, root volume, and the number of root tips (Table 1 and Table 2).

\subsection{Assessment of the Number of Spores of Mycorrhizal Fungi in Rhizosphere Soil}

Rhizosphere soil samples collected in July 2013 from each replication were used to weigh out $100 \mathrm{~g}$ portions of the soil for further analysis. They were then placed in bottle containers and made up to 11 with distilled water. Thus prepared samples were shaken for about $1 \mathrm{~h}$ and then placed in a refrigerator $\left(24 \mathrm{~h}, 4^{\circ} \mathrm{C}\right)$. After $24 \mathrm{~h}$ the soil solution was filtered through a column of sieves (in a successive series: $0.5 \mathrm{~mm}, 0.125 \mathrm{~mm}, 0.0063 \mathrm{~mm}$, and $0.0045 \mathrm{~mm})$. The soil fraction remaining on each sieve was washed off with distilled water into a Petri dish (120 $\mathrm{mm}$ ), to which sucrose was added (5 g per dish). Thus prepared samples were examined using a Nikon SMZ 800

Table 1. Effect of biopreparations on root growth characteristics of ELSANTA strawberry plants. Analysis of the results in July 2013.

\begin{tabular}{|c|c|c|c|c|c|}
\hline Treatment & $\begin{array}{l}\text { Root length } \\
\text { (cm/plant) }\end{array}$ & $\begin{array}{l}\text { Root surface area } \\
\left(\mathrm{cm}^{2} / \text { plant }\right)\end{array}$ & $\begin{array}{l}\text { Root diameter } \\
(\mathrm{mm} / \text { plant })\end{array}$ & $\begin{array}{l}\text { Root volume } \\
\left(\mathrm{cm}^{3} / \text { plant }\right)\end{array}$ & $\begin{array}{l}\text { Number of root tips } \\
\text { (per plant) }\end{array}$ \\
\hline Control & $306 \mathrm{c}$ & $102 \mathrm{ab}$ & $1.06 \mathrm{~b}$ & $2.70 \mathrm{bc}$ & $1407 \mathrm{bc}$ \\
\hline Control NPK & $442 \mathrm{~d}$ & $136 \mathrm{c}$ & $0.98 \mathrm{ab}$ & $3.34 \mathrm{c}$ & $1604 \mathrm{c}$ \\
\hline Manure & $254 \mathrm{bc}$ & $125 \mathrm{~b}$ & $1.57 \mathrm{c}$ & $4.93 \mathrm{e}$ & $1162 \mathrm{~b}$ \\
\hline Micosat + Manure & $357 \mathrm{c}$ & $149 \mathrm{~d}$ & $1.33 \mathrm{bc}$ & $4.93 \mathrm{e}$ & $1868 \mathrm{~d}$ \\
\hline Humus UP & $307 \mathrm{c}$ & $88 \mathrm{a}$ & $0.91 \mathrm{ab}$ & $2.00 \mathrm{ab}$ & $1247 \mathrm{~b}$ \\
\hline Humus Active + Aktywit PM & $184 \mathrm{a}$ & $94 \mathrm{a}$ & $1.62 \mathrm{c}$ & $3.81 \mathrm{c}$ & $627 \mathrm{a}$ \\
\hline BF Quality + Manure & $236 \mathrm{~b}$ & $81 \mathrm{a}$ & $1.09 \mathrm{~b}$ & $2.19 \mathrm{~b}$ & $1126 \mathrm{~b}$ \\
\hline BF Amin + Manure & $391 \mathrm{~cd}$ & $130 \mathrm{c}$ & $1.06 \mathrm{~b}$ & $3.45 \mathrm{c}$ & $944 \mathrm{ab}$ \\
\hline Manure + Tytanit & $227 \mathrm{~b}$ & $75 \mathrm{a}$ & $1.05 \mathrm{~b}$ & $1.98 \mathrm{a}$ & $965 \mathrm{ab}$ \\
\hline Vinassa + Manure & $373 \mathrm{c}$ & $143 \mathrm{~d}$ & $1.22 \mathrm{bc}$ & $4.37 \mathrm{~d}$ & $1026 \mathrm{~b}$ \\
\hline Florovit Pro Natura & $437 \mathrm{~d}$ & $127 \mathrm{~b}$ & $0.92 \mathrm{ab}$ & $2.92 \mathrm{bc}$ & $1913 \mathrm{~d}$ \\
\hline Florovit Eko & $509 \mathrm{e}$ & $87 \mathrm{a}$ & $0.55 \mathrm{a}$ & $1.19 \mathrm{a}$ & $4770 \mathrm{e}$ \\
\hline
\end{tabular}

Means in columns marked with the same letter do not differ significantly at $p=0.05$ according to Tukey's multiple test. 
Table 2. Effect of biopreparations on root growth characteristics of ELKAT strawberry plants. Analysis of the results in July 2013.

\begin{tabular}{|c|c|c|c|c|c|}
\hline Treatment & $\begin{array}{l}\text { Root length } \\
\text { (cm/plant) }\end{array}$ & $\begin{array}{l}\text { Root surface area } \\
\left(\mathrm{cm}^{2} / \text { plant }\right)\end{array}$ & $\begin{array}{l}\text { Root diameter } \\
\text { (mm/plant) }\end{array}$ & $\begin{array}{l}\text { Root volume } \\
\left(\mathrm{cm}^{3} / \text { plant }\right)\end{array}$ & $\begin{array}{l}\text { Number of root tips } \\
\text { (per plant) }\end{array}$ \\
\hline Control & $1409 \mathrm{f}$ & $559 \mathrm{e}$ & $1.24 \mathrm{bc}$ & $17.3 \mathrm{~g}$ & $13397 \mathrm{~d}$ \\
\hline Control NPK & $215 \mathrm{a}$ & $64 \mathrm{a}$ & $0.95 \mathrm{a}$ & $1.53 \mathrm{a}$ & $629 a$ \\
\hline Manure & $418 \mathrm{c}$ & $149 \mathrm{~b}$ & $1.13 \mathrm{bc}$ & $4.22 \mathrm{~d}$ & $1064 \mathrm{ab}$ \\
\hline Micosat + Manure & $477 \mathrm{c}$ & $138 \mathrm{~b}$ & $0.92 \mathrm{a}$ & $3.16 \mathrm{c}$ & $1818 \mathrm{~b}$ \\
\hline Humus UP & $290 \mathrm{ab}$ & $116 \mathrm{~b}$ & $1.27 \mathrm{bc}$ & $3.69 \mathrm{c}$ & $837 \mathrm{a}$ \\
\hline Humus Active + Aktywit PM & $205 \mathrm{a}$ & $92 \mathrm{ab}$ & $1.42 \mathrm{c}$ & $3.26 \mathrm{c}$ & $994 \mathrm{ab}$ \\
\hline BF Quality + Manure & $1412 \mathrm{f}$ & 476 de & $1.07 \mathrm{ab}$ & $12.8 \mathrm{f}$ & $14580 \mathrm{~d}$ \\
\hline $\mathrm{BF}$ Amin + Manure & $1045 \mathrm{~d}$ & $410 \mathrm{~d}$ & $1.25 \mathrm{bc}$ & $12.8 \mathrm{f}$ & $14090 \mathrm{~d}$ \\
\hline Manure + Tytanit & $336 \mathrm{~b}$ & $109 \mathrm{ab}$ & $1.03 \mathrm{ab}$ & $2.82 \mathrm{~b}$ & $945 \mathrm{ab}$ \\
\hline Vinassa + Manure & $1183 \mathrm{~d}$ & $401 \mathrm{~cd}$ & $1.08 \mathrm{ab}$ & 10.8 ef & $15600 \mathrm{e}$ \\
\hline Florovit Pro Natura & $1439 \mathrm{f}$ & $346 \mathrm{c}$ & $0.78 \mathrm{a}$ & $6.74 \mathrm{e}$ & $10526 \mathrm{c}$ \\
\hline Florovit Eko & $453 \mathrm{c}$ & $156 \mathrm{bc}$ & $1.09 \mathrm{ab}$ & $4.28 \mathrm{~d}$ & $1449 \mathrm{~b}$ \\
\hline
\end{tabular}

Means in columns marked with the same letter do not differ significantly at $p=0.05$ according to Tukey's multiple test.

stereoscopic microscope, fishing out and counting the spores of mycorrhizal fungi found in them [23] [24] (Table 3).

\subsection{Statistical Analysis}

The results were statistically analyzed using one-way analysis of variance, in a system of random blocks. Multiple comparisons of the means for combinations were performed with Tukey's test at a significance level of $\alpha=$ 0.05, using Statistica 10 software (StatSoft, Inc., 2011).

\section{Results and Discussion}

The results of the experiments indicate a positive influence of the applied bioproducts on root growth characteristics and the degree of mycorrhizal association in the roots of strawberry plants of the cultivars Elsanta and Elkat. The bioproducts contributed to an increase in the number of spores of AMF and the total number of soil bacteria. The biopreparations: BioFeed Quality, BioFeed Amin, Vinassa and Florovit Eko increased the intensity of root growth (root growth parameters) in strawberry plants in comparison with the control plants fertilized with NPK (Table 1 and Table 2). Application of BioFeed Quality contributed to a six-fold increase in root length, and a seven-fold increase in root surface area. Compared to NPK fertilization, application of the preparation BioFeed Amin resulted in an eight-fold increase in root volume, and the biofertilizer Vinassa increased as much as 24-fold the number of root tips in Elkat strawberry plants. The number of root tips in Elsanta plants fertilized with the biofertilizer Florovit Eko increased three-fold in relation to the roots of plants fertilized with NPK. Compared to the roots of the strawberry cultivar Elsanta, the cultivar Elkat was characterized by longer roots, with a larger diameter, volume and surface area, and a greater number of root tips. Similar results on the beneficial effects of the same bioproducts on the growth of strawberry plants of the cultivar Elsanta in a greenhouse experiment had been obtained by Sas Paszt et al. [25]. On the basis of these results it can be concluded that Micosat, Humus UP, manure, and Vinassa have a beneficial effect on root growth characteristics as compared to control plants fertilized with NPK. Also Malusa et al. [26], in a greenhouse experiment, had reported a positive influence of fertilization with biopreparations on root growth in three varieties of strawberry plants.

The tested biopreparations also had a positive influence on the degree of mycorrhizal association and the number of AMF spores obtained from the rhizosphere soil of strawberry plants. Micosat F and Humus UP con- 
tributed to a five-fold increase in mycorrhizal frequency, while the preparation Micosat $\mathrm{F}$ and manure increased from two to four times the number of spores in the rhizosphere soil of strawberry plants (Table 3). The roots of Elsanta plants were more frequently colonized by AMF than the roots of the cultivar Elkat. In the rhizosphere soil of Elkat strawberry plants, a greater number of spores was observed than in the soil collected from under the plants of the cultivar Elsanta. Sas Paszt et al. [25], in a greenhouse experiment, had reported similar results for Elsanta plants. They observed that the preparations Micosat F and Humus UP increased twenty-fold the degree of mycorrhizal association in the roots, and Micosat F and BioFeed Amin contributed to the increase in the number of spores of AMF in the rhizosphere of strawberry plants. Malusa et al. [26] had found that inoculation of the roots of strawberry plants with the preparation Micosat F significantly increased the number of spores in the rhizosphere of the strawberry cultivars in the study.

The applied biopreparations such as Humus UP, BioFeed Amin and Florovit Eko contributed to a doubling of the total number of bacteria and filamentous fungi in the rhizosphere soil of Elsanta and Elkat strawberry plants compared to NPK fertilization (Table 4). The soil from the root zone of Elsanta plants was characterized by a greater number of bacteria and filamentous fungi than the rhizosphere soil collected from under the plants of the cultivar Elkat. Similar results were obtained by Ding et al. [27], who conducted an assessment of rhizosphere bacteria and the effects of biofertilizers in reducing bacterial wilt in potatoes under greenhouse conditions. They found that the use of the biofertilizers $\mathrm{BIO} 23$ and BIO36 increased the overall population of bacteria and actinomycetes, while organic fertilization (compost) increased the total number of fungi. Pešaković et al. [28] studied the effect of biofertilizers (PGPR 1 and PGPR 2 inocula) on yield characteristics and the population of soil microorganisms in the rhizosphere of the strawberry cultivar Senga Sengana under controlled conditions. They showed that PGPR 1 increased three times the overall number of microorganisms and the number of actinomycetes, while the application of PGPR 2 resulted in a doubling of the total number of fungi and the total number of azotobacter bacteria in the soil.

Sas Paszt et al. [29] examined the effects of biostimulators on plant growth and crop size and quality in strawberry plants of the cultivars Elsanta and Honeoye. Their results suggest that the use of the preparation Vinassa and BioFeed Amin, and the biopreparations Humus UP and Humus Active + Aktywit PM improved the yield and weight of strawberry fruit, and also the green colour of the leaves of strawberry plants, compared to control plants. The best yields and the heaviest fruits were produced by strawberry plants of the cultivar Elsanta as a result of foliar spraying with the preparation Vinassa.

Table 3. Effect of biopreparations on mycorrhizal frequency ( $\mathrm{F} \%)$ in the roots and the number of spores in the soil collected from under ELSANTA and ELKAT strawberry plants. Analysis of the results in July 2013.

\begin{tabular}{ccccc}
\hline \multirow{2}{*}{ Treatment } & \multicolumn{2}{c}{ Mycorrhizal frequency F\% } & \multicolumn{2}{c}{ Number of spores } \\
\cline { 2 - 5 } & ELSANTA (\%) & ELKAT (\%) & ELSANTA & ELKAT \\
Control & $15.6 \mathrm{ab}$ & $14.4 \mathrm{ab}$ & $58 \mathrm{c}$ & $117 \mathrm{~d}$ \\
Control NPK & $6.67 \mathrm{a}$ & $7.78 \mathrm{a}$ & $35 \mathrm{a}$ & $29 \mathrm{a}$ \\
Manure & $25.6 \mathrm{c}$ & $24.4 \mathrm{cde}$ & $72 \mathrm{~d}$ & $135 \mathrm{e}$ \\
Micosat + Manure & $36.7 \mathrm{e}$ & $46.6 \mathrm{f}$ & $83 \mathrm{e}$ & $45 \mathrm{~b}$ \\
Humus UP & $40.0 \mathrm{e}$ & $30.0 \mathrm{e}$ & $47 \mathrm{~b}$ & $47 \mathrm{~b}$ \\
Humus Active + Aktywit PM & $30.0 \mathrm{~cd}$ & $28.9 \mathrm{de}$ & $73 \mathrm{~d}$ & $63 \mathrm{c}$ \\
BF Quality + Manure & $24.4 \mathrm{bc}$ & $21.1 \mathrm{~cd}$ & $39 \mathrm{a}$ & $68 \mathrm{c}$ \\
BF Amin + Manure & $26.7 \mathrm{c}$ & $20.0 \mathrm{c}$ & $65 \mathrm{~cd}$ & $66 \mathrm{c}$ \\
Manure + Tytanit & $21.1 \mathrm{bc}$ & $21.1 \mathrm{~cd}$ & $57 \mathrm{c}$ & $56 \mathrm{bc}$ \\
Vinassa + Manure & $25.6 \mathrm{c}$ & $25.6 \mathrm{cde}$ & $59 \mathrm{c}$ & $61 \mathrm{c}$ \\
Florovit Pro Natura & $26.7 \mathrm{c}$ & $25.6 \mathrm{cde}$ & $81 \mathrm{e}$ & $32 \mathrm{ab}$ \\
Florovit Eko & $27.8 \mathrm{c}$ & $24.4 \mathrm{cde}$ & $41 \mathrm{ab}$ & $33 \mathrm{ab}$ \\
\hline
\end{tabular}

Means in columns marked with the same letter do not differ significantly at $p=0.05$ according to Tukey's multiple test. 
Table 4. Effect of biopreparations on the total number of bacteria and fungi in the soil collected from under ELSANTA and ELKAT strawberry plants. Analysis of the results in July 2013.

\begin{tabular}{ccccc}
\hline & \multicolumn{2}{c}{ ELSANTA } & \multicolumn{2}{c}{ ELKAT } \\
\cline { 2 - 5 } Treatment & $\begin{array}{c}\text { Total number of bacteria } \\
\times 10^{6}{\mathrm{cfu} \cdot \mathrm{g}^{-1} \mathrm{DWs}^{*}}^{*}\end{array}$ & $\begin{array}{c}\text { Total number of fungi } \\
\times 10^{4} \mathrm{cfu} \cdot \mathrm{g}^{-1} \mathrm{DWs}\end{array}$ & $\begin{array}{c}\text { Total number of bacteria } \\
\times 10^{6} \mathrm{cfu} \cdot \mathrm{g}^{-1} \mathrm{DWs}\end{array}$ & $\begin{array}{c}\text { Total number of fungi } \\
\times 10^{4} \mathrm{cfu}^{-1} \mathrm{DWs}\end{array}$ \\
\hline Control & $199 \mathrm{~d}$ & $50.5 \mathrm{~b}$ & $73.9 \mathrm{~b}$ & $52.8 \mathrm{~b}$ \\
Control NPK & $95.0 \mathrm{~b}$ & $45.6 \mathrm{ab}$ & $79.0 \mathrm{~b}$ & $60.3 \mathrm{bc}$ \\
Manure & $82.6 \mathrm{~b}$ & $39.2 \mathrm{a}$ & $121 \mathrm{c}$ & $62.9 \mathrm{bc}$ \\
Micosat + Manure & $74.4 \mathrm{ab}$ & $40.3 \mathrm{ab}$ & $112 \mathrm{c}$ & $54.2 \mathrm{~b}$ \\
Humus UP & $113 \mathrm{c}$ & $103 \mathrm{~d}$ & $65.3 \mathrm{~b}$ & $53.7 \mathrm{~b}$ \\
Humus Active + Aktywit PM & $67.7 \mathrm{a}$ & $76.9 \mathrm{c}$ & $41.8 \mathrm{a}$ & $56.6 \mathrm{~b}$ \\
BF Quality + Manure & $65.6 \mathrm{a}$ & $25.7 \mathrm{a}$ & $73.1 \mathrm{~b}$ & $89.3 \mathrm{c}$ \\
BF Amin + Manure & $41.9 \mathrm{a}$ & $57.7 \mathrm{~b}$ & $97.2 \mathrm{bc}$ & $49.1 \mathrm{ab}$ \\
Manure + Tytanit & $88.9 \mathrm{~b}$ & $89.9 \mathrm{c}$ & $54.7 \mathrm{ab}$ & $61.5 \mathrm{bc}$ \\
Vinassa + Manure & $94.8 \mathrm{~b}$ & $88.3 \mathrm{c}$ & $53.2 \mathrm{ab}$ & $62.6 \mathrm{bc}$ \\
Florovit Pro Natura & $60.9 \mathrm{a}$ & $38.8 \mathrm{a}$ & $60.8 \mathrm{~b}$ & $24.7 \mathrm{a}$ \\
\hline Florovit Eko & $136 \mathrm{c}$ & $41.6 \mathrm{ab}$ & $142 \mathrm{~d}$ & \\
\hline
\end{tabular}

${ }^{*}$ Colony-forming units per 1 gram dry weight of the soil. Means in columns marked with the same letter do not differ significantly at $p=0.05$ according to Tukey's multiple test.

Development and implementation in practice of new microbiological biopreparations is essential for the development of ecological and sustainable methods of crop production. This will increase the competitiveness and profitability of Polish enterprises in the horticultural and agricultural production sector.

\section{Conclusions}

1) The cultivar Elkat was characterized by a larger root system and a greater number of spores in the rhizosphere soil than the cultivar Elsanta;

2) Arbuscular mycorrhizal fungi colonized the roots of Elsanta plants more frequently than those of Elkat. In the rhizosphere soil of the cultivar Elsanta, the reported number of bacteria and filamentous fungi was higher than that of the cultivar Elkat;

3) The tested biopreparations, Micosat F, Humus UP, Humus Active + Aktywit PM, BioFeed Amin, Vinassa, Florovit Eko and Florovit Pro Natura, favorably influenced the intensity of root growth, the degree of mycorrhizal association, the number of spores of arbuscular mycorrhizal fungi, and the total number of fungi in the cultivar Elsanta.

This publication is part of the project "Development of Innovative Products and Technologies for Organic Cultivation of Fruit Plants" with an acronym EkoTechProdukt, co-financed by the European Regional Development Fund, Innovative Economy Operational Programme 2007-2013, Sub-Measure 1.3.1 OP IE.

\section{References}

[1] Azcón-Aquilar, C. and Barea, J.M. (1992) Interactions between Mycorrhizal Fungi and Other Rhizosphere Microorganisms. In: Allen, M.J., Ed., Mycorrhizal Functioning, an Integrative Plant-Fungal Process, Chapman and Hall, New York, 163-198.

[2] Smith, S.E. and Read, D.J. (1997) Mycorrhizal Symbiosis. Academic Press, London, 605.

[3] Linderman, R.G. (2000) Effects of Mycorrhizas on Plant Tolerance to Diseases. In: Kapulnik, Y. and Douds Jr., D.D., Eds., Arbuscular Mycorrhizas: Physiology and Function, Kluwer Academic Publishers, Dordrecht, 345-365.

[4] Cox, G. and Tinker, B.B. (1976) Translocation and Transfer of Nutrients in Vesicular-Arbuscular Mycirrhizas I. The 
Arbuscule and Phosphorus Transfer: Quantitative Ultrastruktural Study. New Phytologist, 77, 371-378. http://dx.doi.org/10.1111/j.1469-8137.1976.tb01526.x

[5] Vessey, J.K. (2003) Plant Growth Promoting Rhizobacteria as Biofertilizers. Plant and Soil, 255, 571-586. http://dx.doi.org/10.1023/A:1026037216893

[6] Glick, B.R. (1995) The Enhancement of Plant Growth by Free Living Bacteria. Canadian Journal of Microbiology, 41, 109-117. http://dx.doi.org/10.1139/m95-015

[7] Jeffries, P., Gianinazzi, S., Perotto, S., Turnau, K. and Barea, J.M. (2003) The Contribution of Arbuscular Mycorrhizal Fungi in Sustainable Maintenance of Plant Health and Soil Fertility. Biology and Fertility of Soils, 37, 1-16.

[8] Zahir, Z.A., Arshad, M. and Frankenberger, W.T. (2004) Plant Growth Promoting Rhizobacteria: Applications and Perspectives in Agriculture. Advances in Agronomy, 81, 97-168. http://dx.doi.org/10.1016/S0065-2113(03)81003-9

[9] Maciejewska, A. and Kwiatkowska, J. (2001) Wpływ nawozu organiczno-mineralnego z węgla brunatnego na plony i zawartość K, Mg, Ca w roślinach. Zeszyty Problemowe Postepow Nauk Rolniczych, 480, 281-289.

[10] Nardi, S., Pizzeghello, D., Muscolo, A. and Vianello, A. (2002) Physiological Effects of Humic Substances on Higher Plants. Soil Biology \& Biochemistry, 34, 1527-1536. http://dx.doi.org/10.1016/S0038-0717(02)00174-8

[11] Litterick, A.M., Harrier, L., Wallace, P., Watson, C.A. and Wood, M. (2004) The Role of Uncomposted Materials, Composts, Manures and Compost Extracts in Reducing Pest and Disease Incidence and Severity in Sustainable Temperate Agricultural and Horticultural Crop Production-A Review. Critical Reviews Plant Sciences, 23, 453-479. http://dx.doi.org/10.1080/07352680490886815

[12] Turgay, O.C., Karaca, A., Unver, S. and Tamer, N. (2011) Effects of Coal-Derived Humic Substance on Some Soil Properties and Bread Wheat Yield. Communications in Soil Science and Plant Analysis, 42, 1050-1070 http://dx.doi.org/10.1080/00103624.2011.562586

[13] Sobiczewski, P. (2001) Stan obecny i perspektywy ochrony sadów i szkółek przed chorobami bakteryjnymi. Progress in Plant Protection, 41, 291-298.

[14] Sobiczewski, P., Berczyński, S., Szczepaniak, J., Filip, A., Włodarczyk, S. and Majdziak, K. (2001) Sposób wytwarzania biopreparatu na podłożu stałym do ochrony podkładek drzew owocowych i róży przed guzowatością korzeni. Patents, 3, B1 (11) 16767547.

[15] Utkhede, R.S. and Smith, E.M. (1992) Promotion of Apple Growth and Fruit Production by the EBW-4 Strain of Bacillus subtilis in Apple Replant Disease Soil. Canadian Journal of Microbiology, 38, 1270-1273. http://dx.doi.org/10.1139/m92-209

[16] Utkhede, R.S. and Smith, E.M. (1993) Evaluation of Monoammonium Phosphate and Bacterial Strains to Increase Tree Growth and Fruit Yield in Apple Replant Problem Soil. Plant and Soil, 157, 115-120. http://dx.doi.org/10.1007/BF02390233

[17] Mazzola, M., Granatstein, D.M., Elfving, D.C., Mullinix, K. and Gu, Y.H. (2002) Cultural Management of Microbial Community Structure to Enhance Growth of Apple in Replant Soils. Phytopathology, 92, 1363-1366. http://dx.doi.org/10.1094/PHYTO.2002.92.12.1363

[18] Vieira, F.C.S. and Nahas, E. (2005) Comparison of Microbial Numbers in Soils by Using Various Culture Media and Temperatures. Microbiological Research, 160, 197-202. http://dx.doi.org/10.1016/j.micres.2005.01.004

[19] Chang, E.H., Chung, R.S. and Tsai, Y.H. (2007) Effect of Different Application Rates of Organic Fertilizer on Soil Enzyme Activity and Microbial Population. Soil Science and Plant Nutrition, 53, 132-140. http://dx.doi.org/10.1111/j.1747-0765.2007.00122.x

[20] Derkowska, E., Sas Paszt, L., Sumorok, B. and Dyki, B. (2013) Colonization of Apple and Blackcurrant Roots by Arbuscular Mycorrhizal Fungi Following Mycorrhization and the Use of Organic Mulches. Folia Horticulturae, 25, $117-$ 122. http://dx.doi.org/10.2478/fhort-2013-0013

[21] Trouvelot, A., Kough, J.L. and Gianinazzi-Pearson, V. (1986) Mesure du taux de mycorhization VA d'un systeme radiculaire. Recherche de methods d'estimation ayant une signification fonctionnelle. In: Gianinazzi-Pearson V. and Gianinazzi, S., Eds., Physiological and Genetical Aspects of Mycorrhizae, Inra, Paris, 217-221.

[22] Arsenault, J.L., Poulcur, S., Messier, C. and Guay, R. (1995) WIN-RHIZO a Root-Measuring System with a Unique Overlap Correction Method. HortScience, 30, 906.

[23] Błaszkowski, J. (2003) Arbuscular Mycorrhizal Fungi (Glomeromycota). Endogone and Complexipes Species Deposited in the Department of Plant Pathology, University of Agriculture in Szczecin, Poland. http://www.zor.zut.edu.pl/Glomeromycota/

[24] Błaszkowski, J. (2008) Metody izolowania, hodowania i identyfikowania arbuskularnych grzybów mikoryzowych z gromady Glomeromycota. In: Mułenko, W., Ed., Mykologiczne Badania Terenowe. Przewodnik Metodyczny, Wydawnictwo UMCS, Lublin, 142-163. 
[25] Sas Paszt, L., Sumorok, B., Malusá, E., Głuszek, S. and Derkowska, E. (2011) The Influence of Bioproducts on Root Growth and Mycorrhizal Occurrence in the Rhizosphere of Strawberry Plants "Elsanta". Journal of Fruit and Ornamental Plant Research, 19, 13-34.

[26] Malusà, E., Sas-Paszt, L., Popińska, W. and Żurawicz, E. (2007) The Effect of a Substrate Containing Arbuscular Mycorrhizal Fungi and Rhizosphere Microorganisms (Trichoderma, Bacillus, Pseudomonas and Streptomyces) and Foliar Fertilization on Growth Response and Rhizosphere $\mathrm{pH}$ of Three Strawberry Cultivars. International Journal Fruit Science, 6, 25-41. http://dx.doi.org/10.1300/J492v06n04_04

[27] Ding, C., Shen, Q., Zhang, R. and Chen, W. (2013) Evaluation of Rhizosphere Bacteria and Derived Bio-Organic Fertilizers as Potential Biocontrol Agents against Bacterial Wilt (Ralstonia solanacearum) of Potato. Plant Soil, 366, $453-$ 466. http://dx.doi.org/10.1007/s11104-012-1425-y

[28] Pešaković, M., Karaklajić-Stajić, Ž., Milenković, S. and Mitrović, O. (2013) Biofertilizer Affecting Yield Related Characteristics of Strawberry (Fragaria $\times$ ananassa Duch.) and Soil Micro-Organisms. Scientia Horticulturae, 150, 238-243. http://dx.doi.org/10.1016/j.scienta.2012.11.016

[29] Sas Paszt, L., Frąc, M. and Przybył, M. (2013) Biostymulatory w uprawie truskawek. Jagodnik, 6, 4-7. 
Scientific Research Publishing (SCIRP) is one of the largest Open Access journal publishers. It is currently publishing more than 200 open access, online, peer-reviewed journals covering a wide range of academic disciplines. SCIRP serves the worldwide academic communities and contributes to the progress and application of science with its publication.

Other selected journals from SCIRP are listed as below. Submit your manuscript to us via either submit@scirp.org or Online Submission Portal.
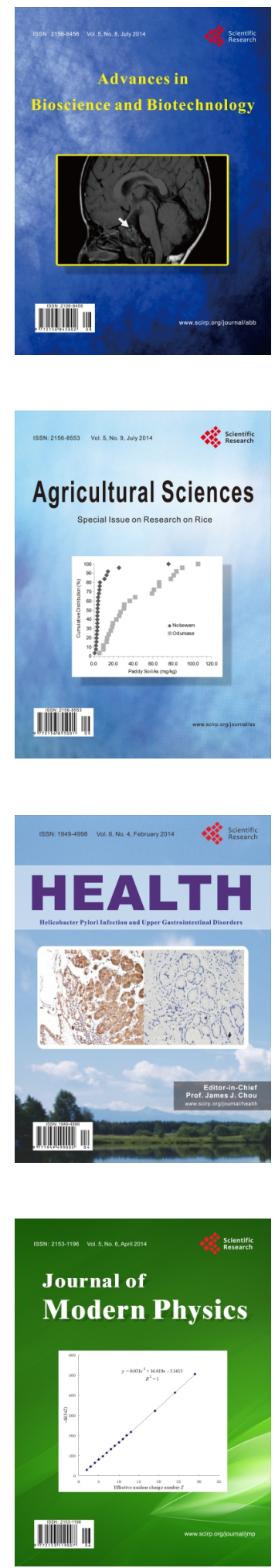
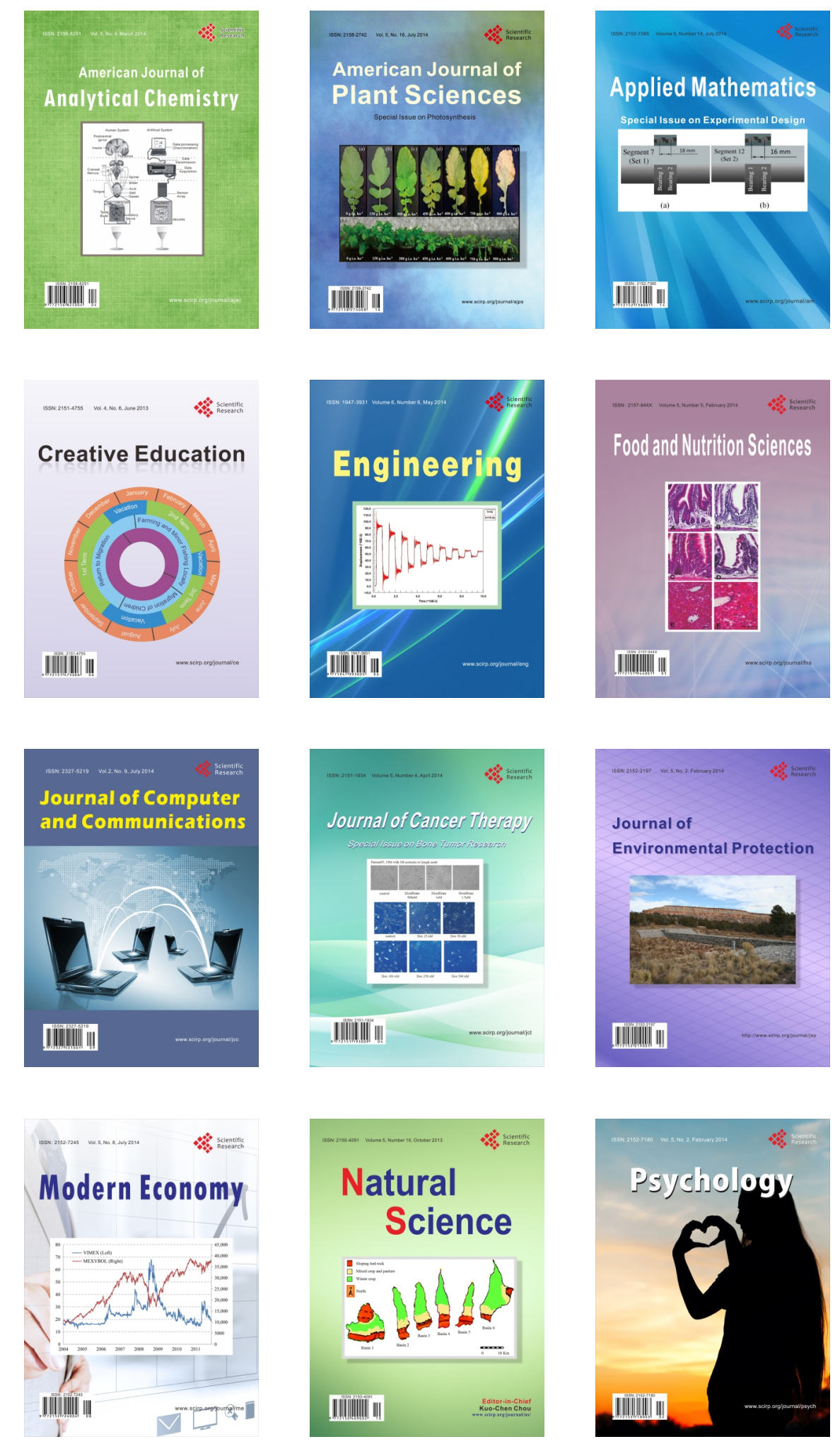